\title{
The Epidemiology of the Trichodinid Ciliate Trichodina truttae on Hatchery-reared and Wild Salmonid Fish in Hokkaido
}

\author{
Shinya Mizuno ${ }^{1 *}$, Shigehiko Urawa ${ }^{2}$, Mahito Miyamoto ${ }^{1}$, Makoto Hatakeyama ${ }^{1}$, \\ Hayato Saneyoshi ${ }^{1}$, Yoshitaka Sasaki ${ }^{1}$, Nobuhisa Koide ${ }^{1}$ and Hiroshi Ueda ${ }^{3}$ \\ ${ }^{1}$ Salmon and Freshwater Fisheries Research Institute, Hokkaido Research Organization, Hokkaido 061-1433, Japan \\ ${ }^{2}$ Hokkaido National Fisheries Research Institute, Japan Fisheries Research and Education Agency, \\ Hokkaido 062-0922, Japan \\ ${ }^{3}$ Field Science Center for Northern Biosphere, Graduate School of Environmental Science, \\ Hokkaido University, Hokkaido 060-0809, Japan
}

(Received September 27, 2016)

\begin{abstract}
Trichodinids are ectoparasitic ciliates that infect the body surface of salmonid fish and occasionally cause high mortality in juvenile chum salmon Oncorhynchus keta reared at hatcheries in northern Japan. The present study examined the occurrence of trichodinid ciliates on wild fish and hatchery-reared juvenile chum salmon in Hokkaido to determine the epidemiology of these parasites. Trichodinids were observed on juvenile chum salmon reared at 28 out of the 87 examined hatcheries and on wild fish, including masu salmon $O$. masou, rainbow trout $O$. mykiss, adult chum salmon, white-spotted char Salvelinus leucomaenis, and Dolly Varden S. malma in rivers. All isolates of trichodinid ciliates had the same nucleotide sequences of small subunit ribosomal RNA gene and were identified morphologically as $T$. truttae. A transmission experiment showed that $T$. truttae was transmitted horizontally from wild masu salmon to hatchery-reared juvenile chum salmon. Our results demonstrate that a dominant species of trichodinid ciliate infecting salmonid fish in Hokkaido is $T$. truttae and that wild salmonids can be an infection source of hatchery-reared juvenile chum salmon.
\end{abstract}

Key words: Trichodina truttae, Oncorhynchus keta, Oncorhynchus mykiss, Salvelinus leucomaenis, Salvelinus malma, hatchery, Hokkaido, Epidemiology

Trichodina species are ectoparasitic ciliates that infect the skin and/or gills of fish. These parasites are common and occasionally cause trichodinosis, which can be lethal for cultured freshwater and marine fish (Lom and Hoffman, 1964; Hoffman, 1976; Lom and Dyková, 1992; Urawa, 1992a; Khan, 2004). The identification of Trichodina species in Japanese fish has been limited; $T$. reticulata has been detected on goldfish Carassius auratus auratus, silver crucian carp Carassius auratus langsdorfii, and common carp Cyprinus carpio (Ahmed, 1977); T. truttae has been observed on chum salmon Oncorhynchus keta (Urawa and Arthur, 1991); $T$. japonica, $T$. jadranica, and $T$. acuta have been found on Japanese eel Anguilla japonica (Imai et al., 1991); and $T$. fugu has been identified on tiger puffer Takifugu rubripes (Imai et al., 1997).

Epidemiological information on $T$. truttae, which was originally identified on hatchery-reared cutthroat trout $O$. clarki in Oregon, USA (Mueller, 1937), has been reported in Canada (Arthur and Margolis, 1984; Khan,

\footnotetext{
* Corresponding author

E-mail: mizuno-shinya@hro.or.jp
}

1991) and Japan (Urawa, 1992a, b). Infections of the parasite are widely observed on hatchery-reared juvenile chum salmon in the regions of Hokkaido and Tohoku, northern Japan, but have not been reported on hatcheryreared pink salmon $O$. gorbuscha, masu salmon $O$. masou, or sockeye salmon O. nerka (Urawa, 1992b). Results of a transmission experiment revealed that a heavy $T$. truttae infection causes epidermal hyperplasia on the skin of juvenile chum salmon and cumulative mortality of $56 \%$, with intensive flashing and jumping out of the water (Urawa, 1992a). In fact, high mortalities due to trichodinid infections occurred in chum salmon fry reared in a Hokkaido hatchery in 1968 (Takeda et al., 1969). It is important for hatchery managers to control the parasite using seawater baths (Khan, 1991) and to intercept the infection routes of the parasite to prevent mortality of juvenile chum salmon due to trichodinosis. It is presumed that wild fish inhabiting rivers are the source of $T$. truttae infection because these infections are often found in hatcheries that utilize river water to culture juveniles (Urawa, 1992b). However, this hypothesis has not been proven because little information is available on $T$. truttae infections in wild fish. 
Taxonomic studies of $T$. truttae have been performed by morphological observations using light and scanning electron microscopy (Arthur and Margolis, 1984; Urawa and Arthur, 1991; Ferguson et al., 2011) but no study has used a molecular approach to investigate the epidemiology of the parasite. The complete and partial nucleotide sequences of the small subunit ribosomal RNA gene (SSUrDNA) have been elucidated to identify and classify several Trichodina species (Zhan et al., 2009; Gong et al., 2010; Tang et al., 2013), but that of $T$. truttae have not been reported.

To determine the epidemiological characteristics of $T$. truttae including the infection sources of hatchery fish, the present study examined the occurrence of trichodinid ciliates on juvenile chum salmon reared at 87 hatcheries and wild fish captured from rivers in Hokkaido. The ciliates were identified morphologically and their SSUrDNA sequences were compared between isolates. A transmission experiment of trichodinid ciliates was performed between wild masu salmon and hatchery-reared juvenile chum salmon.

\section{Materials and Methods}

Fish

Juvenile chum salmon (weight, 0.83-1.20 g) were collected from 87 hatcheries in Hokkaido from April to May 2013. The hatcheries were designated nos. 1-87. The name and location of each hatchery was de-identified to prevent any harm caused by a fish disease rumor. Wild fish composed of masu salmon, rainbow trout $O$. mykiss, white-spotted char Salvelinus leucomaenis, Dolly Varden S. malma, sculpin Cottus nozawae, and goby Gymnogobius urotaenia were captured $50-200 \mathrm{~m}$ upstream from the water intake point of each river where hatchery nos. 42, 43, 60, 66, 67, 69-71, and 77 were located by electrofishing (LR-24 Backpack Electrofisher; Smith-Root, Vancouver, WA, USA) from May to November 2013 (Table 1). In addition, 10 wild adult chum salmon migrating upstream to spawn were caught using fixed cages in the river of the hatchery no. 43 on October 8 and in the river of hatchery no. 66 on November 4, 2013 (Table 1). The captured fish were held individually until sampling to prevent horizontal infection of trichodinid ciliates. Hatchery-reared juveniles and wild fishes excepting adult chum salmon were

Table 1. Wild fish collected in this study and infection status of trichodinid ciliates on the fish

\begin{tabular}{|c|c|c|c|c|c|c|}
\hline \multicolumn{2}{|l|}{ Sampling } & \multicolumn{3}{|c|}{ Fish } & \multicolumn{2}{|c|}{ Infection status of trichodinid ciliates } \\
\hline Date & River & Species & Number & Body weight $(\mathrm{g})$ & $\begin{array}{l}\text { The parasite number } \\
\text { (individual/g body weight) }\end{array}$ & $\begin{array}{l}\text { The parasite- } \\
\text { positive rate of } \\
\text { fish }(\%)\end{array}$ \\
\hline May 8, 2013 & No. 42 & Masu salmon & 10 & $0.35-13.0$ & 0 & $0 *(0 / 10)$ \\
\hline \multirow[t]{4}{*}{ May 9,2013} & No. 43 & Masu salmon & 21 & $18.3-47.4$ & $0.846 \pm 2.21$ & $62.5 *(5 / 8)$ \\
\hline & & Rainbow trout & 34 & $18.5-77.1$ & $0.00404 \pm 0.0106$ & $14.2 *(1 / 7)$ \\
\hline & & White-spotted char & 3 & $167.3-457.2$ & $0.00259 \pm 0.00519$ & $33.3 *(1 / 3)$ \\
\hline & & Sculpin & 5 & $0.62-18.1$ & 0 & $0 *(0 / 5)$ \\
\hline \multirow[t]{4}{*}{ July 7, 2013} & No. 60 & Masu salmon & 40 & $1.94-29.9$ & $0.0951 \pm 0.190$ & $14.2 *(1 / 7)$ \\
\hline & & White-spotted char & 29 & $3.30-91.2$ & $0.0684 \pm 0.0931$ & $40.0 *(0 / 10)$ \\
\hline & No. 66 & Masu salmon & 51 & $1.33-13.9$ & $0.135 \pm 0.419$ & $10.5 *(2 / 19)$ \\
\hline & & Dolly Varden & 38 & $1.01-25.5$ & $0.123 \pm 0.350$ & $12.5 *(1 / 8)$ \\
\hline October 8, 2013 & No. 43 & Chum salmon (Adult) & 10 & $2,000-3,500$ & ${ }^{\dagger}$ No data & ${ }^{\dagger}$ No data \\
\hline \multirow[t]{15}{*}{ November 4, 2013} & No. 60 & Masu salmon & 10 & $2.71-34.3$ & $0.107 \pm 0.232$ & $30.0 *(3 / 10)$ \\
\hline & & White-spotted char & 16 & $2.30-5.56$ & $0.0240 \pm 0.0657$ & $12.5 *(2 / 16)$ \\
\hline & No. 66 & Chum salmon (Adult) & 10 & $1,800-3,200$ & ${ }^{\dagger}$ No data & ${ }^{\dagger}$ No data \\
\hline & & Masu salmon & 22 & $2.92-10.9$ & $0.408 \pm 0.997$ & $50.0 *(11 / 22)$ \\
\hline & & Dolly Varden & 8 & $1.23-26.8$ & $0.541 \pm 0.992$ & $37.5 *(3 / 8)$ \\
\hline & No. 67 & Masu salmon & 7 & $11.8-27.9$ & 0 & $0 *(0 / 3)$ \\
\hline & & Dolly Varden & 7 & $3.48-30.8$ & $0.0392 \pm 0.110$ & $14.2 *(1 / 7)$ \\
\hline & No. 69 & Masu salmon & 5 & $10.7-14.22$ & 0 & $0 *(0 / 5)$ \\
\hline & & Dolly Varden & 6 & $3.45-27.7$ & 0 & $0 *(0 / 6)$ \\
\hline & & Goby & 6 & $0.60-9.31$ & 0 & $0 *(0 / 6)$ \\
\hline & No. 70 & Masu salmon & 3 & $7.34-25.7$ & 0 & $0 *(0 / 3)$ \\
\hline & & Dolly Varden & 7 & $1.48-11.2$ & $0.0828 \pm 0.168$ & $28.5 *(2 / 7)$ \\
\hline & No. 71 & Dolly Varden & 6 & $4.39-51.0$ & 0 & $0 *(0 / 6)$ \\
\hline & No. 77 & Rainbow trout & 7 & $18.4-44.1$ & 0 & $0 *(0 / 7)$ \\
\hline & & Dolly Varden & 7 & $4.09-19.9$ & $0.0667 \pm 0.176$ & $14.2 *(1 / 7)$ \\
\hline
\end{tabular}

\footnotetext{
* Asterisks showed number of the parasite-positive fish/total number of fish analyzed infection status of the parasite.

${ }^{\dagger}$ Infection status of trichodinid ciliates on adult chum salmon was not examined in this study.

The parasite numver was expressed as mean \pm standard deviation.
} 
used for analyses on infection status, morphology and SSUrDNA of trichodinid ciliates, while adult chum salmon were done for only analyses on the morphology and rDNA. For the transmission experiment, a total of 1,160 chum salmon were cultured artificially from midNovember 2012 until May 10, 2013 without becoming infected by $T$. truttae, Ichthyobodo salmonis (Urawa, 2013), or Chilodonella piscicola (Urawa and Yamao, 1992), which are ectoparasitic protozoans of juveniles at the Salmon and Freshwater Fisheries Research Institute, Hokkaido, Japan.

\section{Infection status of hatchery-reared chum salmon and} wild fish

Juvenile chum salmon $(n=10)$ obtained from the 87 hatcheries and wild river fish ( $n=3-22)$, except the adult chum salmon, were bathed individually in a 15 or $50 \mathrm{~mL}$ polypropylene conical tube filled with $0.1 \%$ unbuffered tricaine methanesulfonate (MS-222; Sigma-Aldrich, St. Louis, MO, USA) to detach the protozoan ectoparasites from the skin (Callahan and Noga, 2002). After a 10 min incubation at $4^{\circ} \mathrm{C}$, the carcasses were taken out from the tube using sterilized forceps, weighed, and the absence of trichodinid ciliates on their body surface was confirmed under a stereomicroscope (Primo Vert; Carl Zeiss, Jena, Germany). The number of trichodinid ciliates in the MS-222 solution was counted under the stereomicroscope after all of the solution was placed on zooplankton counter glasses using a micropipette. Parasite load was calculated as the number of trichodinid ciliates per $\mathrm{g}$ fish body weight. Data on the parasite load of each group was expressed as mean \pm standard deviation. The positive rates of trichodinid infection on juveniles from each hatchery and those of wild fish from each river were calculated as the percentage of infected samples of the total samples.

\section{Analysis of morphological characteristics}

Some of the juvenile chum salmon cultured at hatchery nos. 43 and 66, the wild masu salmon, rainbow trout, white-spotted char, and Dolly Varden captured from river nos. 43, 60, and 66 in May and July (as shown in Table 1); and all wild adult chum salmon were used to observe trichodinid ciliate morphology. The trichodinid ciliates were collected by smearing abdominal skin and scrapings from all fins of the fish on slide glasses followed by air-drying. The smears were immersed in $2 \%$ silver nitrate solution for $10 \mathrm{~min}$ and exposed to ultraviolet light for 15 min using a UV crosslinker (XL-1000 UV Crosslinker; Spectronics, New York, NY, USA) according to the dry silver-impregnation method (Klein, 1958) to clear the trichodinid ciliate structure. The characters used to identify the trichodinids included body diameter, the adhesive disc and denticulate ring, the numbers of denticles and radial pins per denticle, the length dimensions of the blade, thorn, center, and span in the denticle; the width of the border membrane; and the adoral ciliary spiral. These parameters were measured using a three-dimensional high-resolution image analysis system (Apotome 2 and Axio Imager System; Carl Zeiss), according to methods reported by Lom (1958) and Gong et al. (2005).

\section{SSUrDNA sequencing analysis}

Immediately after smearing the trichodinid ciliates, the carcasses of the juveniles and wild fish and caudal fins excised from adult chum salmon using anatomical scissors were individually bathed completely in MS-222 solution and removed from the tubes as aforementioned. For each fish species and each river, solutions were mixed together as a single sample. After $>10$ trichodinid ciliates were confirmed to be in the solution using a stereomicroscope, the solution was centrifuged at $3,000 \times g$ for $15 \mathrm{~min}$ at $4^{\circ} \mathrm{C}$, and the supernatant was removed with a micropipette. Total DNA and partial RNA were extracted from the precipitate using a nucleic acid extraction kit (SepaGene; Eidia, Tokyo, Japan) and resuspended in $20 \mu \mathrm{L}$ Tris-EDTA buffer (10 mM Tris- $\mathrm{HCl}$ and $1 \mathrm{~mm}$ EDTA, pH 8.0). The polymerase chain reaction (PCR) was performed to amplify the PCR products originating from the partial SSUrDNA using a primer set common to all trichodinid ciliates (Medlin et al., 1988). The nucleotide sequences of the primers were 5'-AACCTGGTTGATCCTGCC-3' for the forward primer and 5'-TGATCCTTCTGCAGGTTC-3' for the reverse primer. A $25 \mu \mathrm{L}$ aliquot of the PCR mixture was comprised of $2 \mu \mathrm{L}$ nucleic acid template, $12.5 \mu \mathrm{L} 2 \times$ PCR mixture (AmpliTaq Gold 360 Master Mix; Applied Biosystems, Foster City, CA, USA), $0.25 \mu \mathrm{L}$ of $50 \mu \mathrm{m}$ forward primer, $0.25 \mu \mathrm{L}$ of $50 \mu \mathrm{M}$ reverse primer, and $10 \mu \mathrm{L}$ distilled water. The thermal cycles for PCR were one cycle of enzyme activation for $10 \mathrm{~min}$ at $95^{\circ} \mathrm{C}, 40$ cycles of denaturation for $30 \mathrm{~s}$ at $95^{\circ} \mathrm{C}$, primer annealing for 30 $\mathrm{s}$ at $58^{\circ} \mathrm{C}$, extension for $2 \min 72^{\circ} \mathrm{C}$, and one cycle of complete extension for $7 \mathrm{~min}$ at $72^{\circ} \mathrm{C}$. The amplified PCR products were ligated into the pCR2.1 plasmid vector and isolated using a TA Cloning kit (Invitrogen, Carlsbad, CA, USA). At least 100 PCR products for each fish species and each river were sequenced in both directions using an automated ABI PRISM 377 DNA sequencer (Applied Biosystems), dye terminators, and M13 forward and M13 reverse primers. The trichodinid rDNA sequence data were registered at the DNA Data Bank of Japan (http://www.ddbj.nig.ac.jp/index-j. html).

\section{SSUrDNA phylogenetic tree analysis}

Partial SSUrDNA nucleotide sequences of nine Trichodina species and two Trichodinella species (family Trichodinidae) were obtained from the Genbank database under the following accession numbers: $T$. reticulata (AY741784: Gong et al., 2006); T. heterodentata 
(AY788099: Gong et al., 2006); Trichodinella myakkae (AY102176: Gong et al., 2006); T. nobilis (AY102172); T. ruditapicis (FJ499385: Zhan et al., 2009); T. sinovaculae (FJ499386: Zhan et al., 2009); T. meretricis (FJ499387: Zhan et al., 2009); T. hypsilepis (EF524274); Trichodinella epizootica (GU906246: Tang et al., 2013); T. pectenis (JQ663868: Zhan et al., 2013); and T. sinipercae (EF599288). A multiple sequence alignment analysis was performed, and a phylogenetic tree was constructed using the neighbor-joining method and ClustalW ver. 2.1 software (http://clustalw.ddbj.nig.ac.jp/index.php?lang=ja.) at the DNA Data Bank of Japan by running 1,000 bootstrap replicates.

\section{Transmission experiment}

The trichodinid ciliate transmission experiment was performed at the Salmon and Freshwater Fisheries Research Institute, Hokkaido, Japan on May 10, 2013. Three groups of 380 juvenile chum salmon (mean weight: $1.05 \mathrm{~g}$ ) not infected with $T$. truttae were introduced into $25-L$ tanks supplied with spring water $\left(8^{\circ} \mathrm{C}\right)$ at a flow rate of $3.6 \mathrm{~L} / \mathrm{min}$. A net basket (size: $15 \times$ $10 \times 15 \mathrm{~cm}$, net opening: $2 \times 2 \mathrm{~mm}$ ) was floated in each tank to separate the infected from the uninfected fish. One group was the uninfected control. The other two groups placed in baskets were infected and comprised of either 10 juvenile chum salmon (mean weight: $0.97 \mathrm{~g}$ ) obtained from hatchery no. 43 or 10 wild juvenile masu salmon (mean weight: $22.8 \mathrm{~g}$ ) captured from river no. 43 on May 9, 2013 (Table 1). On May 17 (day 7), all net baskets containing the infected fish were removed from the tanks. Thereafter, the three groups were reared until June 14 (day 35). Commercial trout crumbles were supplied at approximately $2 \%$ body weight/day to each group, and mortality was checked daily during the 35- day experiment. Dead fish were removed daily to prevent any deterioration in water quality. Ten fish from each group were sampled at 7- day intervals. The parasite load was examined according to the analysis of infection status of hatchery-reared juveniles. Data on mortality are presented as a weekly cumulative percentage of mortality at 7- day intervals. In addition, species identification of trichodinid ciliates, which infected uninfected juvenile chum salmon by this transmission experiment, was not performed in the two infected groups.

\section{Statistical analysis}

Comparisons of the parasite numbers between June and November on wild fish of nos. 60 and 66 and of those between any two transmission experiment groups at each sampling time, as well as the sampling times in each transmission experiment group were performed with Mann-Whitney's $U$ test after confirmation of non-normality on data by test of normality. Significant difference was accepted when $U$-value was out of the range between two significance $U$ points determined at significance level of 5\%. Morphological measurements of the trichodinid ciliates were compared among hatchery-reared juveniles and wild fish with one-way analysis of variance after confirmation of homoscedasticity on data by Bartlett test. In this analysis, A $P$-value $<0.05$ was considered significant. All statistical analysis were performed using Statcel2 (OMS Publishing, Saitama, Japan).

\section{Results}

Infection status of hatchery-reared juvenile chum salmon

Trichodinid infections on juvenile chum salmon were observed at 28 of the 87 hatcheries, and the parasite load ranged from $0.0612 \pm 0.244$ to $156 \pm 126$ individuals/g body weight (Fig. 1). The rates of trichodinid infection among juveniles in each of the 28 parasitepositive hatcheries ranged between 10 and $100 \%$, and 25 of 28 hatcheries had infection rates $<100 \%$. Trichodinid infections were detected in seven (nos. 43, $60,66,67,70,71$, and 77 ) of the nine hatcheries utilizing rivers where the infection status of wild river fish was examined, and the infection rates were $30-100 \%$.

\section{Infection status of wild fish}

Trichodinid infections were found on wild fish in six (river nos. 43, 60, 66, 67, 70, and 77 ) of nine rivers but were not observed in the other three rivers (river nos. 42 , 69, and 71) (Table 1). Parasite infections were detected on masu salmon in three of seven rivers (0.0951 $\pm 0.190-0.846 \pm 2.21$ individuals/g body weight), on rainbow trout $(0.00404 \pm 0.0106$ individuals $/ g$ body weight) in one of two rivers, on white-spotted char $(0.00259 \pm 0.00519-0.0684 \pm 0.0931$ individuals/g body weight) in three of three rivers, and on Dolly Varden $(0.0392 \pm 0.111-0.541 \pm 0.992$ individuals $/ g$ body weight) in four of six rivers but were not found on sculpin or goby. The rate of trichodinid infection among infected wild fish ranged from 10.5 to $62.5 \%$ on masu salmon, from 12.5 to $40.0 \%$ on white-spotted char, from 12.5 to $37.5 \%$ on Dolly Varden, and $14.2 \%$ on rainbow trout. No seasonal variations between July and November in mean parasite numbers on masu salmon, white-spotted char, or Dolly Varden were detected in river nos. 60 or 66 .

\section{Morphological characteristics}

Figure 2 shows a typical trichodinid ciliate that infected hatchery-reared chum salmon and wild salmonids. The denticle blade was acutely falcate with a largely concave anterior border and sharply angled posterior margin. The blade connected with the central part of the denticle posterior to the median axis of the thorn. The thorn was thicker at the base and tapered off to a sharp point. Table 2 compares the morphological 

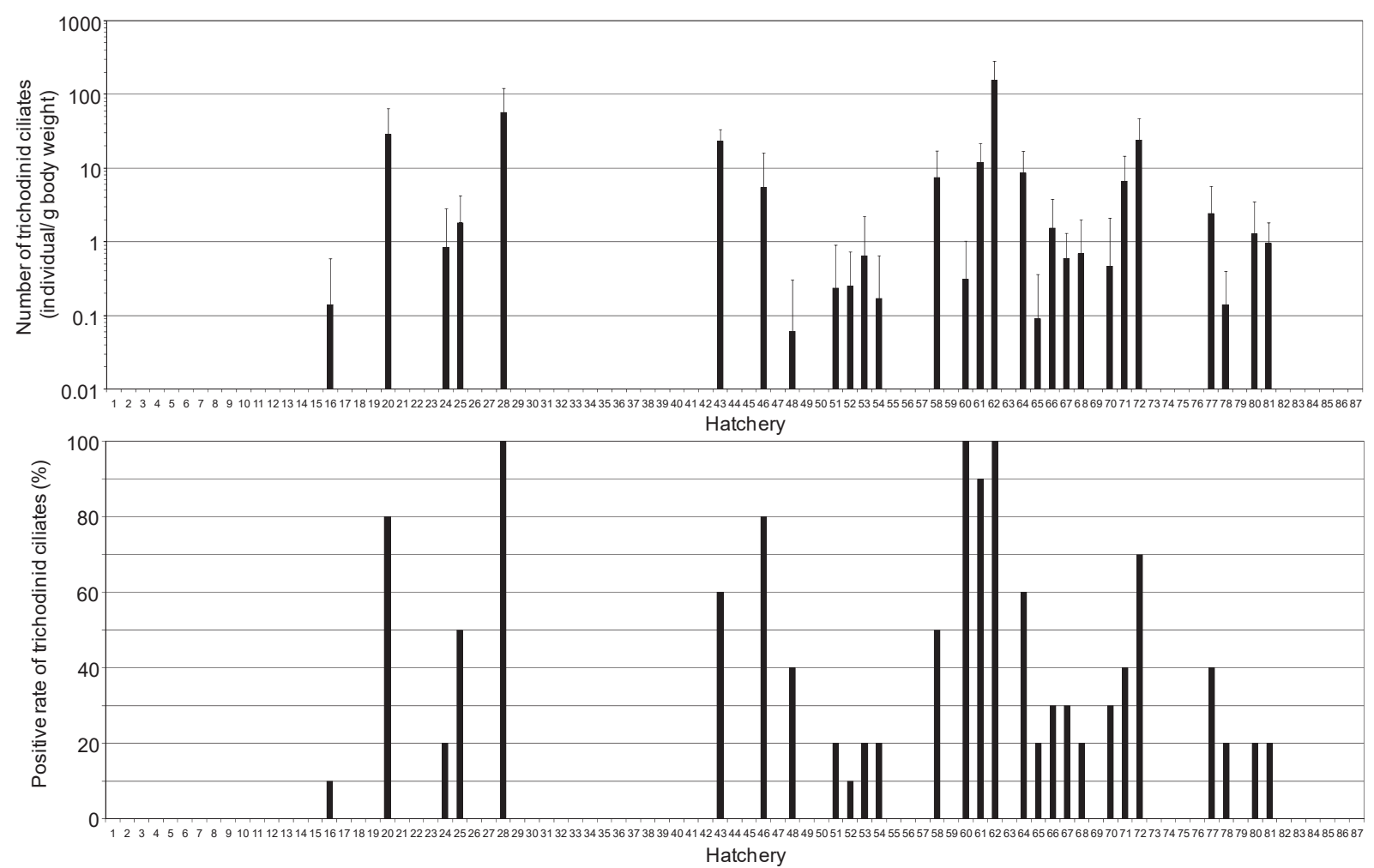

Fig. 1. Infection status of trichodinid ciliates in juvenile chum salmon reared in salmon hatcheries.

Upper and lower graphs show average number of trichodinid ciliates infecting juvenile chum salmon (individual/g body weight) and the percentage of the parasite infection on the juvenile in each hatchery (\%), respectively. Data on the number of trichodinid ciliates was expressed as mean \pm standard deviation $(n=10)$.

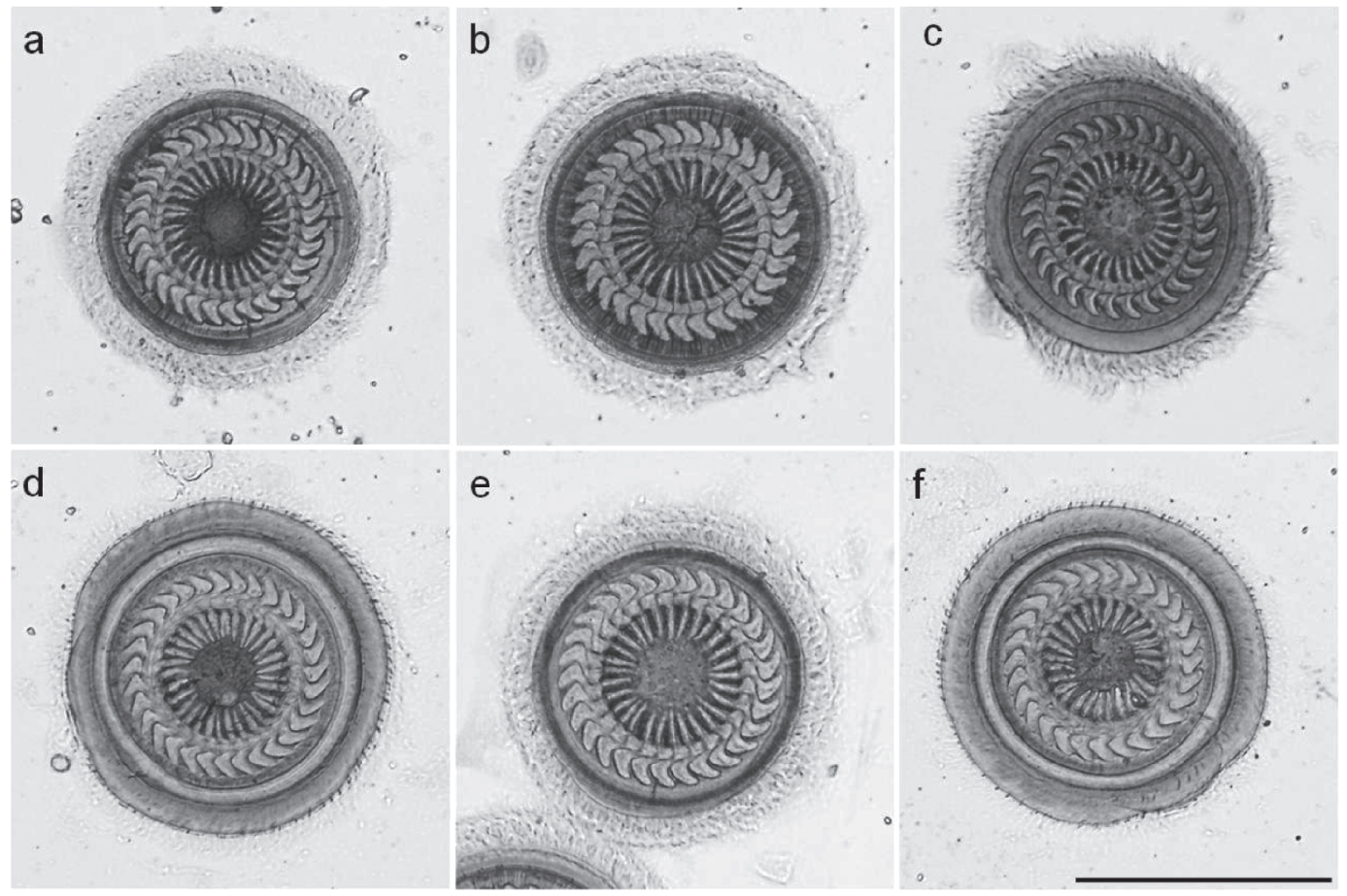

Fig. 2. Photomicrographs of trichodinid ciliates from hatchery-reared juvenile chum salmon and wild adult chum salmon, masu salmon, rainbow trout, white-spotted char and dolly varden.

Photographs a, b, c, d, e and f show trichodinid ciliates from no. 43 hatchery-reared juvenile chum salmon, wild adult chum salmon of the no. 43 river, wild masu salmon of the no. 43 river, wild rainbow trout of the no. 43 river, wild white-spotted char of the no.60 river and wild Dolly Varden of the no.66 river, respectively. Scale bar shows $100 \mu \mathrm{m}$. 


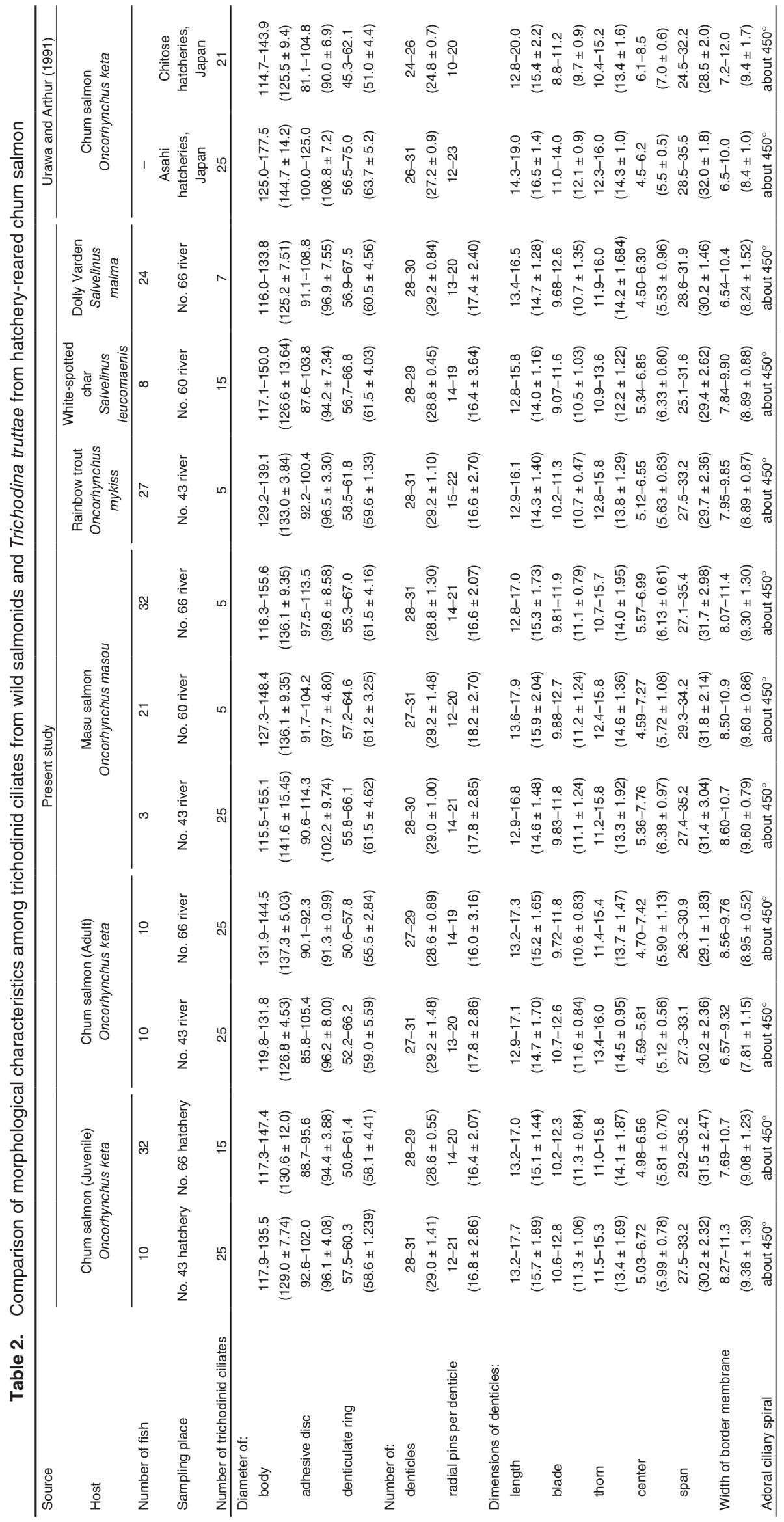


characteristics of the trichodinid ciliates from hatcheryreared chum salmon and wild salmonids, as well as $T$. truttae reported by Urawa and Arthur (1991). All of the trichodinid ciliates had a disc-shaped body (115.3-155.6 $\mu \mathrm{m}$ in diameter), with an adhesive disc (85.8-114.3 $\mu \mathrm{m}$ in diameter) surrounded by a wide border membrane (6.54-11.4 $\mu \mathrm{m}$ in width). The denticulate ring (50.6$67.5 \mu \mathrm{m}$ in diameter) in the adhesive disc consisted of 27-31 denticles (12.8-11.4 $\mu \mathrm{m}$ in length and 25.1-35.4 $\mu \mathrm{m}$ in span). The denticle was composed of a blade (12.8-11.4 $\mu \mathrm{m}$ in length), a thick central part (4.50-7.76 $\mu \mathrm{m}$ wide), and a thorn (10.7-16.0 $\mu \mathrm{m}$ in length). The adoral ciliary spiral made a turn of about $450^{\circ}$. No differences were observed in the diameters of the body $(P=0.290)$, adhesive disc $(P=0.298)$, denticulate ring $(P=0.287)$, numbers of denticles $(P=0.984)$ radial pins per denticle $(P=0.949)$, dimensions of denticle length $(P=0.726)$, denticle blade $(P=0.810)$, denticle thorn $(P=0.484)$, denticle center $(P=0.410)$, denticle span $(P=0.566)$, or width of the border membrane $(P=$ 0.229 ) among all eight wild fish and two hatchery-reared juvenile chum salmon in the present study. The values of all parameters for all trichodinid ciliates examined in this study were within the range for $T$. truttae reported by Urawa and Arthur (1991) (Table 2).

\section{Molecular analysis}

All isolated trichodinid SSUrDNAs had the same 1,699 base pair nucleotide sequences (Genbank accession number: LC186029), with GC content of $51.2 \%$ and no variations in fish species, sampling location. The results of the multiple sequence alignment analysis indicated that the SSUrDNA of this trichodinid was $95 \%$ homologous with that of $T$. heterodentata, $T$. pectenis, $T$. ruditapicis, T. sinovaculae, and T. nobilis; 94\% homologous with that of Trichodinella myakkae and Trichodinella epizootica, $91 \%$ homologous with that of $T$. sinipercae, $T$. reticulata and $T$. hypsilepis; and $90 \%$ homologous with that of $T$. meretricis. Twelve trichodinid ciliates, including the present trichodinid ciliate, were divided into three distinctly separate phylogenetic tree branches (Fig. 3). The present trichodinid ciliate was grouped together on one of the branches with T. heterodentata, T. pectenis, $T$. ruditapicis, $T$. sinovaculae, $T$. nobilis, and $T$. meretricis, which branched early into a single clade following divergence of $T$. heterodentata and $T$. nobilis in a small clade but was separated clearly from two Trichodinella species and from the other three Trichodina species on other branches.

\section{Transmission experiment}

The initial numbers of parasites on infected fish used for the experiment were $23.3 \pm 10.3$ individuals $/ g$ body weight on juvenile chum salmon (Fig. 1) and $0.847 \pm 2.21$ individuals $/ g$ body weight on wild masu salmon (Table 1). The number of parasites on chum salmon increased $(P<0.01)$ beginning on day 21 (596 \pm 386 individuals/g body weight), reached the maximum $(3,110 \pm 1,220$ individuals/g body weight) on day 28 , and decreased from days 28 to 35 (1,680 $\pm 1,080$ individuals/g body weight) (Fig. 4). The number of parasites on masu salmon increased $(P<0.01)$ from day 28 (203 \pm 260 individuals/g body weight) to 35 (1,350 \pm 818 individuals/g body weight). Trichodinid ciliates did not

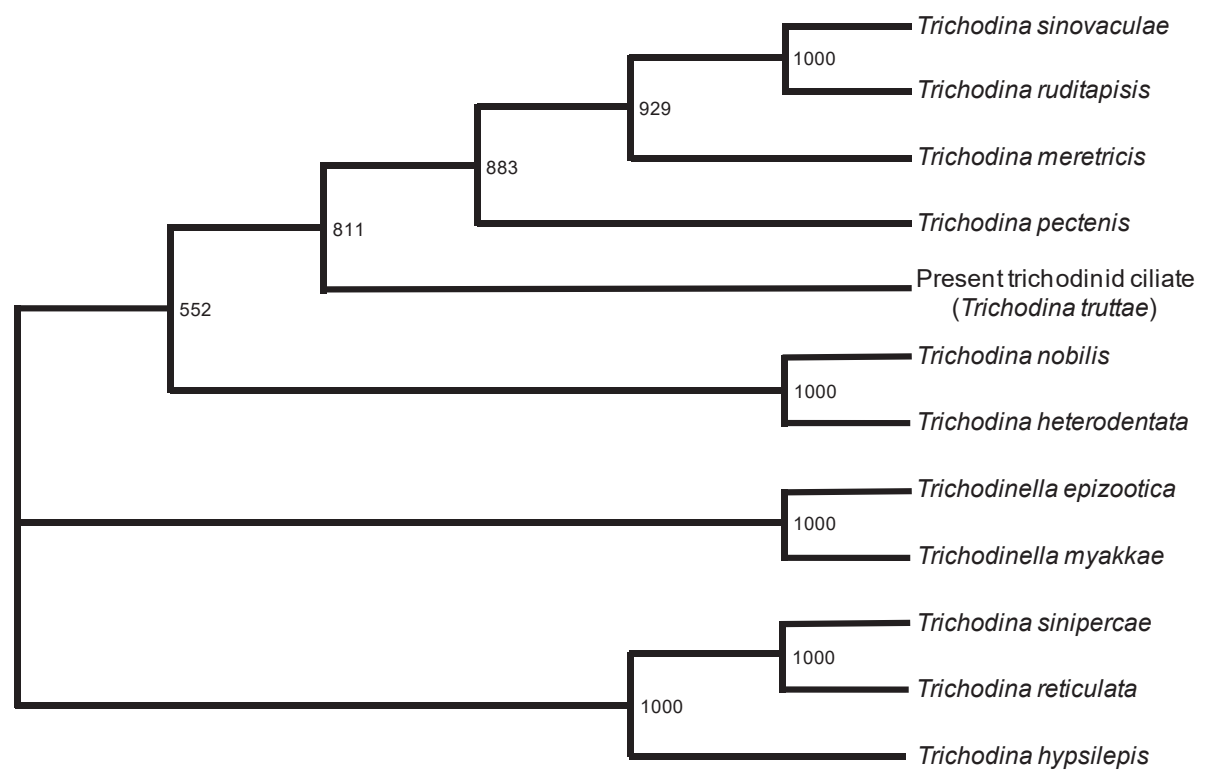

Fig. 3. The phylogenetic tree of present trichodinid ciliates and selected 9 Trichodina species and 2 Tricodinella species inferred from small subunit rDNA sequences.

Phylogenetic tree was constructed by neighbor-joining methods using ClustalW version 2.1 software in the DNA Data Bank of Japan by running 1,000 bootstrap replicates. Figures shown in the phylogenetic tree express bootstrap values of the branch. 

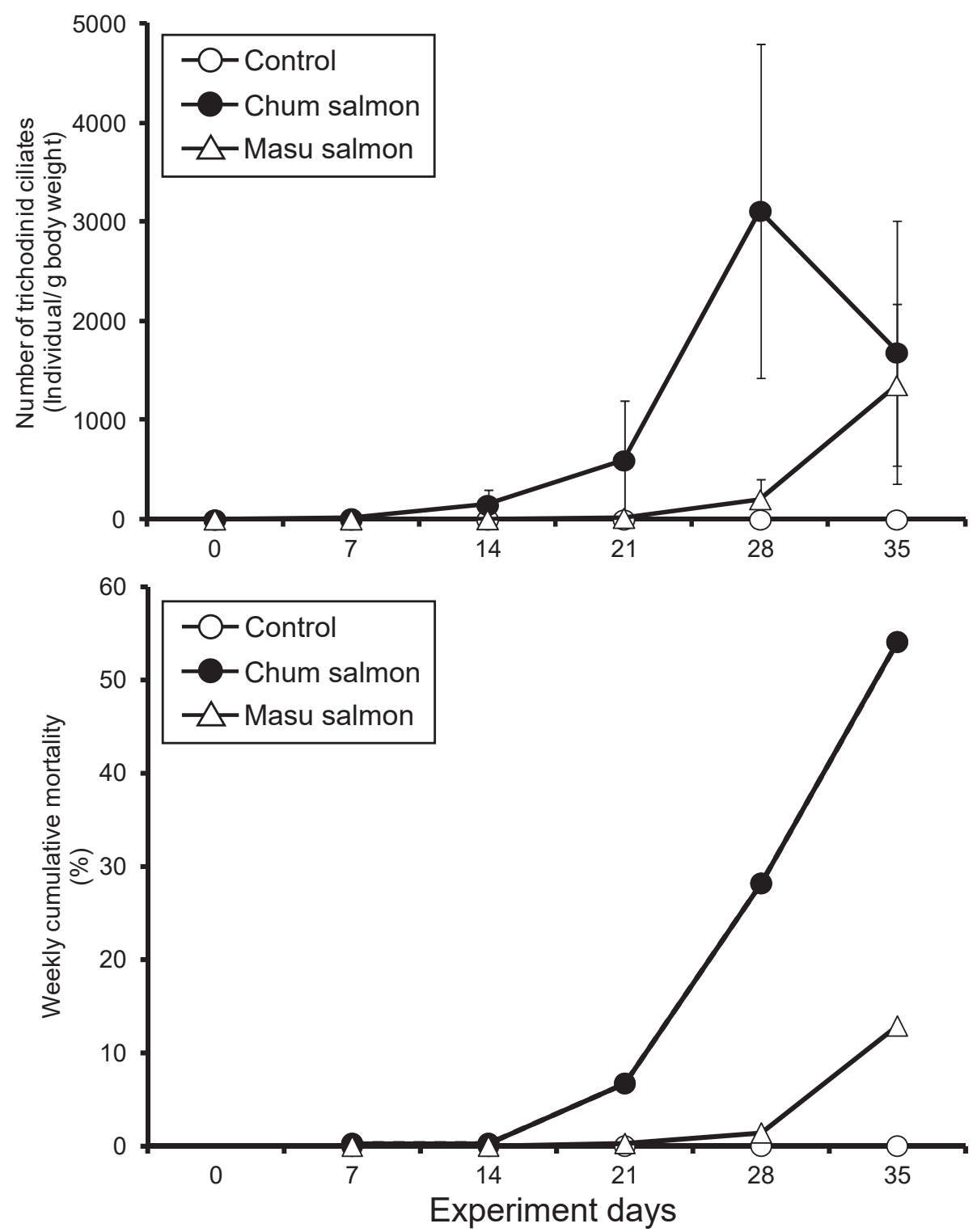

Fig. 4. Changes in number of trichodinid ciliates and weekly cumulative mortality in infected hatchery-reared juvenile chum salmon during the transmission experiment.

Upper and lower graphs show average number of trichodinid ciliates (individual/g body weight) and weekly mortality (\%) in infected juvenile chum salmon by transmission of trichodinid ciliates. Open circles, closed circles and open triangles express control group, infected group by juvenile chum salmon and infected group by masu salmon, respectively. Each data on number of trichodinid ciliates is shown as mean \pm standard deviation $(n=10)$.

parasitize any of the fish in the control group throughout the experiment. Infected chum and masu salmon harbored significantly more parasites than those on the control from days 7 to 35 and from days 14 to 35 , respectively $(P<0.01)$. In addition, significantly more parasites were detected on chum salmon than on masu salmon from days 7 to $28(P<0.01)$. Weekly mortality of chum salmon increased from days $7(0.263 \%)$ to 35 $(54.0 \%)$ and from days $21(0.277 \%)$ to $35(12.9 \%)$ on masu salmon (Fig. 4). On the other hand, no juveniles in the control group died during the experiment.

\section{Discussion}

\section{Species identification}

The shapes of the denticle and adoral ciliary spiral are general morphological taxonomic characteristics of Trichodinidae (Lom and Dyková, 1992). Trichodina species are characterized by robust denticles with welldeveloped thorns and falcated and largely concaved blades with adoral ciliary spiral angles of $360-540^{\circ}$, and all trichodinid ciliates obtained from wild fish and hatchery-reared juvenile chum salmon were Trichodina species. The morphology of $T$. truttae is characterized by a large body (114-177 $\mu \mathrm{m})$ and a large number of radial 
pins per denticle (10-23 pins) (Arthur and Margolis, 1984; Urawa and Arthur, 1991), which are useful features to distinguish $T$. truttae from the smaller $T$. reticulata, $T$. jadranica, and $T$. acuta found on Japanese freshwater fish (Ahmed, 1977; Imai et al., 1991) and other freshwater trichodinid ciliates (Arthur and Lom, 1984; Van As and Basson, 1989). Because all trichodinid ciliates observed in the present study had all of the morphological characteristics of $T$. truttae (Urawa and Arthur, 1991), including a large body and the proper number of radial pins per denticle, they were morphologically identified as T. truttae. Notably, variations in the range of morphological parameters were detected among individual $T$. truttae, sampling locality, and among fish species, which have been reported previously (Urawa and Arthur, 1991; Madsen et al., 2000; Basson, 2010; Yemmen et al., 2010; Miranda et al., 2012). In fact, T. truttae identified by Urawa and Arthur (1991) and the present study showed smaller values in some morphological parameters compared to $T$. truttae identified by Arthur and Margolis (1984). These variations may be affected by development/growth after miniaturization of the body and haploidization of the number of denticles accompanied by binary fission (Van As and Basson, 1989; Nilsen, 1995; Asmat, 2001) or by morphological modifications depending on environmental changes including seasonality (Özer, 2003; Ogut and Altuntas, 2011) and salinity (Özer, 2003).

The SSUrDNA sequencing analysis demonstrated that all trichodinid ciliates examined in the present study genetically consisted of a single Trichodina species with highly homologous SSUrDNA to that of other Trichodina species. A notable point is that GC content, which is useful in trichodinid phylogenetics (Tang et al., 2013), of the present SSUrDNA was $>51 \%$. Because Trichodina species SSUrDNA with $>51 \%$ GC content has not been reported until now, we consider the present SSUrDNA to be that of different Trichodina species from the species whose SSUrDNA nucleotide sequences have been known until now. The phylogenetic tree analysis of trichodinid SSUrDNA revealed that present Trichodina species was distinct from the other nine Trichodina and two Trichodinella species by different branching and the formation of a single clade, which suggest strongly that present trichodinid SSUrDNA is that of $T$. truttae. Interestingly, $T$. truttae was grouped with four seawater Trichodina species, such as $T$. sinovaculae, $T$. ruditapicis, T. meretricis, and T. pectenis, in the original branch. A $T$. truttae infection can be eliminated by a seawater bath (Khan, 1991), whereas 1.0\% brackish water did not control the infection (Mizuno et al., unpublished data), suggesting that $T$. truttae may be slightly adaptable to brackish water.

\section{Transmission experiment}

The present transmission experiment elucidated for the first time that $T$. truttae from masu salmon can infect juvenile chum salmon via the rearing water. This finding reveals that wild masu salmon can be a source of trichodinosis infection for hatchery-reared chum salmon. Our study also showed transmission of $T$. truttae between chum salmon juveniles, as reported previously (Urawa, 1992a). The intensity of the infection caused by chum salmon was stronger than that by masu salmon from days 7 to 28 in the present study, which may have resulted from differences in the initial numbers of parasite on infected fish [mean parasite number (individual $/ \mathrm{g}$ body weight) on chum salmon, 23.3 and masu salmon, 0.847 ] and/or in sensitivity of the host to the parasite, as reported for the ectoparasitic flagellate Ichthyobodo necator (Urawa and Kusakari, 1990) but not in trichodinid ciliates. Comparing these results to those reported previously (Urawa, 1992a), the present transmission reached maximum parasite intensity 1 week later than that of the previous study and the present maximum weekly mortality was about $20 \%$ higher than that reported previously. These variations probably resulted from differences in size, origin, the biological defenses of the experimental fish, and the transmission mode, as the present experiment was performed with caged infected fish, whereas the previous one was performed with the contagion and cohabiting infected and uninfected fish.

\section{Epidemiology of trichodinosis in hatchery and wild fish}

The maximum mean number of $T$. truttae parasites on hatchery-reared juvenile chum salmon (156 individuals/g body weight) (Fig. 1) was less than the mean number of parasites (596 individuals/g body weight) on day 21 of the transmission experiment, when the initial high mortality was observed in the infected chum salmon (Fig. 4). This observation suggests that trichodinosis did not seriously affect the hatcheries examined in the present study. About $32 \%$ of the hatcheries tested positive for $T$. truttae in the present study, whereas the positive rate was $16 \%$ in 1992 (Urawa, 1992b), demonstrating that infection status of chum salmon by $T$. truttae has clearly increased since 1992. The increase may be caused by transportation of hatchery-reared juvenile among hatcheries, which is a common annual practice as a part of the artificial chum salmon propagation program (Kobayashi, 1980). Examining infection status in this study allowed us to monitor the progression of trichodinosis shown by $<100 \%$ infection rates, indicating that surveillance of T. truttae infecting juvenile chum salmon will help prevent trichodinosis in salmon hatcheries of Hokkaido.

The examination of wild fish infection status demonstrated that a dominant species of trichodinid ciliate infecting salmonid fishes in Hokkaido was $T$. truttae. In contrast, Urawa (1992b) reported no T. truttae infections in hatchery-reared masu salmon. This discrepancy may be associated with the above-mentioned greater 
distribution of $T$. truttae since 1992. Infection of wild fish by trichodinid ciliates has been reported worldwide (Arthur and Lom, 1984; Asmat, 2001; Özer and Öztürk, 2004; Dove and O'Donoghue, 2005; Mitra and Haldar, 2005; Mitra and Bandyopadhyay, 2006; Tang and Zhao, 2013; Tang et al., 2013) and varies seasonally in intensity (Özer, 2000; Özer, 2003; Yemmen et al., 2010). However, no seasonal variation in infection intensity was detected at river nos. 60 and 66 between June and November in the present study, indicating that a specific analysis of seasonal variation is required to clarify the whole picture. Checking the infection status of wild fish (Table 1) along with that of hatchery-reared juvenile chum salmon (Fig. 1) showed that infection of wild fish was associated with infection of hatchery-reared juveniles, except river and hatchery no. 71, suggesting that not only wild masu salmon but wild rainbow trout, whitespotted char, and Dolly Varden are trichodinosis infection sources for hatchery-reared chum salmon. In contrast, disagreement with this suggestion was found between hatchery-reared juveniles and wild river fish of no. 71 , which can be explained by following discussion. Because no. 71 hatchery-reared juveniles were originally cultured in hatchery no. 66 and transferred from hatchery no. 66 to no. 71 at fry stage, infection sources for no. 71 hatchery juveniles are possibly no. 66 wild river fishes. On the other hand, we were unable to demonstrate the epidemiology of $T$. truttae on wild adult chum salmon, which are another suspected infection source. The infection route mediated by wild adult chum salmon must be elucidated to prevent trichodinosis in hatcheries.

\section{Acknowledgements}

The authors are grateful to the staff of the Hokkaido Salmon Propagation Association and the Salmon and Freshwater Fisheries Research Institute of Hokkaido Research Organization for help with sample collection. This study was supported by JSPS KAKENHI Grant Number 15K07564.

\section{References}

Ahmed, A. T. A. (1977): Morphology and life history of Trichodina reticulata from goldfish and other carps. Fish Pathol., 12, 21-31.

Arthur, J. R. and J. Lom (1984): Trichodinid Protozoa (Ciliophora: Peritrichida) from freshwater fishes of Rybinsk Reservoir, USSR. J. Protozool., 31, 82-91.

Arthur, J. R. and L. Margolis (1984): Trichodina truttae Mueller, 1937 (Ciliophora: Peritrichida), a common pathogenic ectoparasite of cultured juvenile salmonid fishes in British Columbia: redescription and examination by scanning electronmicroscopy. Can. J. Zool., 62, 1842-1848.

Asmat, G. S. M. (2001): Trichodina cancilae sp. n. (Mobilia: Trichodinidae) from the gills of a freshwater gar, Xenentodon cancila (Hamilton) (Belonidae). Acta Proto- zool., 40, 141-146.

Basson, L. (2010): First records of trichodinid ectoparasites (Ciliophora: Peritrichia) from introduced freshwater fishes in Tasmania, Australia, with comments on pathogenicity. Acta Protozool., 49, 253-265.

Callahan, H. A. and E. J. Noga (2002): Tricaine dramatically reduces the ability to diagnose protozoan ectoparasite (Ichthyobodo necator) infections. J. Fish Dis., 25, 433437.

Dove, A. D. M. and P. J. O'Donoghue (2005): Trichodinids (Ciliophora: Trichodinidae) from native and exotic Australian freshwater fishes. Acta Protozool., 44, 51-60.

Ferguson, J. A., S. St-Hilaire, T. S. Peterson, K. J. Rodnick and M. L. Kent (2011): Survey of parasites in threatened stocks of coho salmon (Oncorhynchus kisutch) in Oregon by examination of wet tissues and histology. J. Parasitol., 97, 1085-1098.

Gong, Y., Y. Yu, W. Feng and Y. Shen (2005): Phylogenetic relationships among Trichodinidae (Ciliophora: Peritrichia) derived from the characteristic values of denticles. Acta Protozool., 44, 237-243.

Gong, Y., Y. Yu, E. Villalobo, F. Zhu and W. Miao (2006): Reevaluation of the phylogenetic relationship between Mobilid and Sessilid Peritrichs (Ciliophora, Oligohymenophorea) based on small subunit rRNA genes sequences. J. Eukaryot. Microbiol., 53, 397-403.

Gong, Y., K. Xu, Z. Zhan, Y. Yu, X. Li, E. Villalobo and W. Feng (2010): Alpha-tubulin and small subunit rRNA phylogenies of Peritrichs are congruent and do not support the clustering of Mobilids and Sessilids (Ciliophora, Oligohymenophorea). J. Eukaryot. Microbiol., 57, 265-272.

Hoffman, G. L. (1976): Parasites of North American freshwater fishes. University of California Press, Berkeley, $486 \mathrm{p}$.

Imai, S., H. Miyazaki and K. Nomura (1991): Trichodinid species from the gill of cultured Japanese eel, Anguilla japonica, with the description of a new species based on light and scanning electron microscopy. Europ. J. Protistol., 27, 79-84.

Imai, S., K. Inoue, T. Kotani and K. Ogawa (1997): Two trichodinid species from the gills of cultured tiger puffer. Takifugu rubripes, in Japan, with the description of a new species. Fish Pathol., 32, 1-6.

Khan, R. A. (1991): Mortality in Atlantic salmon (Salmo salar) associated with trichodinid ciliates. J. Wildlife Dis., 27, 153-155.

Khan, R. A. (2004): Disease outbreaks and mass mortality in cultured Atlantic cod, Gadus morhua L., associated with Trichodina murmanica (Ciliophora). J. Fish Dis., 27, 181-184.

Klein, B. M. (1958): The dry silver method and its proper use. J. Protozool., 5, 99-103.

Kobayashi, T. (1980): Salmon propagation in Japan. In "Salmon Ranching" (ed. by J. E. Thorpe). Academic Press, London, pp. 91-107.

Lom, J. (1958): A contribution to the systematics and morphology of endoparasitic trichodinids from amphibians with a proposal of uniform specific characteristics. J. Protozool., 5, 251-263.

Lom, J. and I. Dyková (1992): Protozoan Parasites of Fishes, Developments in Aquaculture and Fisheries Science Vol. 26, Elsevier, Amsterdam, $315 \mathrm{p}$.

Lom, J. and G. L. Hoffman (1964): Geographic distribution of some species of trichodinids (Ciliate: Peritrichia) parasitic on fishes. J. Parasitol., 50, 30-35.

Madsen, H. C. K., K. Buchmann and S. Mellergaard (2000): Trichodina sp. (Ciliophora: Peritrichida) in eel Anguilla anguilla in recirculation systems in Denmark: host-parasite 
relations. Dis. Aquat. Org., 42, 149-152.

Medlin, L., H. J. Elwood, S. Stickel and M. L. Sogin (1988): The characterization of enzymatically amplified eukaryotic 16S-like rRNA-coding regions. Gene, 71, 491-499.

Miranda, L. H., N. Marchiori, C. R. Alfaro and M. L. Martins (2012): First record of Trichodina heterodentata (Ciliophora: Trichodinidae) from Arapaima gigas cultivated in Peru. Acta Amazonica, 42, 433-438.

Mitra, A. K. and P. K. Bandyopadhyay (2006): Trichodina haldari n. sp. and Paratrichodina Bassonae n. sp. (Ciliophora: Peritrichida) from Indian Fresh Water Fishes. Acta Protozool., 45, 289-294.

Mitra, A. K. and D. P. Haldar (2005): Descriptions of two new species of the genus Trichodina ehrenberg, 1838 (Protozoa: Ciliophora: Peritrichida) from Indian freshwater fishes. Acta Protozool., 44, 159-165.

Mueller, J. F. (1937): Some species of Trichodina (Ciliata) from fresh water fishes. Trans. Am. Microsc. Soc., 56, 177184.

Nilsen, F. (1995): Description of Trichodina hippoglossi n. sp. from farmed Atlantic halibut larvae Hippoglossus hippoglossus. Dis. Aquat. Org., 21, 209-214.

Ogut, $\mathrm{H}$. and C. Altuntas (2011): Monthly variation in the morphological characteristics of Trichodina sp. (Ciliophora: Peritrichida) found on whiting Merlangius merlangus euxinus. Revista de Biología Marina y Oceanografía, 46, 269-274.

Özer, A. (2000): The occurrence of three species of Trichodina (Ciliophora: Peritrichia) on Cyprinus carpio in relation to culture conditions, seasonality and host characteristics. Acta Protozool., 39, 61-66.

Özer, A. (2003): The occurrence of Trichodina domerguei Wallengren, 1987 and Trichodina tenuidens Fauré-Fremiet, 1944 (Peritrichia) on three-spined stickleback, Gasterosteus aculeatus L., 1758 found in a brackish and freshwater environment. Acta Protozool., 42, 41-46.

Özer, A. and T. Öztürk (2004): Trichodina puytoraci Lom, 1962 and Trichodina lepsii Lom, 1962 (Peritrichial: Ciliophora) infestations on Mugilids caught at the Black Sea coast of Sinop in Turkey. Turk. J. Zool., 28, 179-182.

Takeda, K., T. Nomura, M. Harada and A. Sato (1969): Trichodina found on reared chum salmon fry. Fish and Eggs, 130, 15-18 (In Japanese).

Tang, F. and Y. Zhao (2013): Record of three new Trichodina species (Protozoa, Ciliophora) parasitic on gills of freshwater fishes from Chongqing, China. Afr. J. Microbiol. Res., 7, 1226-1232.

Tang, F., Y. Zhao and A. Warren (2013): Phylogenetic analyses of trichodinids (Ciliophora, Oligohymenophora) inferred from 18S rRNA gene sequence data. Curr. Microbiol., 66, 306-313.

Urawa, S. (1992a): Trichodina truttae Mueller, 1937 (Ciliophora: Peritrichida) on juvenile chum salmon (Oncorhynchus keta): Pathogenicity and host-parasite interactions. Fish Pathol., 27, 29-37.

Urawa, S. (1992b): Host range and geographical distribution of the ectoparasitic protozoans, Ichthyobodo necator, Trichodina truttae and Chilodonella piscicola on hatchery-reared salmonids in northern Japan. Sci. Rep. Hokkaido Salmon Hatchery, 46, 175-203.

Urawa, S. (2013): Control of the parasitic flagellate Ichthyobodo salmonis, a causative agent of marine mortalities of juvenile chum salmon. Nor. Pac. Anadr. Fish Com. Tec. Rep., 9, 214-215.

Urawa, S. and J. R. Arthur (1991): First record of the parasitic ciliate Trichodina truttae Mueller, 1937 on chum salmon fry (Oncorhynchus keta) from Japan. Fish Pathol., 26, 83-89.

Urawa, S. and M. Kusakari (1990): The survivability of the ectoparasitic flagellate Ichthyobodo necator on chum salmon fry (Oncorhynchus keta) in seawater and comparison to Ichthyobodo sp. on Japanese flounder (Paralichthys olivaceus). J. Parasitol., 76, 33-40.

Urawa, S. and S. Yamao (1992): Scanning electron microscopy and pathogenicity of Chilodonella piscicola (Ciliophora) on juvenile salmonids. J. Aquat. Animal Health, 4, 188-197.

Van As, J. G. and L. Basson (1989): A further contribution to the taxonomy of the Trichodinidae (Ciliophora: Peritrichia) and a review of the taxonomic status of some fish ectoparasitic trichodinids. Syst. Parasitol., 14, 157-179.

Yemmen, C., Y. Quilichini, M. H. Ktari, B. Marchand and S. Bahri (2010): Morphological, ecological and histopathological studies of Trichodina gobii Raabe, 1959 (Ciliophora: Peritrichida) infecting the gills of Solea aegyptiaca. Protistology, 6, 258-263.

Zhan, Z., K. Xu, A. Warren and Y. Gong (2009): Reconsideration of phylogenetic relationships of the subclass Peritrichia (Ciliophora, Oligohymenophorea) based on small subunit ribosomal RNA gene sequences, with the establishment of a new subclass Mobilia Kahl, 1993. J. Eukaryot. Microbiol., 56, 552-558.

Zhan, Z., K. Xu and M. Dunthorn (2013): Evaluating molecular support for and against the monophyly of the Peritrichia and phylogenetic relationships within the Mobilida (Ciliophora, Oligohymenophorea). Zool. Scr., 42, 213-226. 